\author{
G. PELLIZZARI
}

\title{
First record and establishment of Chionaspis wistariae Cooley (Hemiptera, Diaspididae) in Europe
}

\begin{abstract}
The occurrence of the Asiatic Diaspidid Chionaspis wistariae Cooley in Europe is reported. The scale was collected on the leaves of an old Wisteria tree growing outdoors in the University Botanical Garden of Cluj Napoca (Romania).

Riassunto - Prima segnalazione e adattamento di Chionaspis wistariae Cooley (Hemiptera, Diaspididae) in Europa

Viene segnalata la presenza nell'Orto Botanico di Cluj Napoca (Romania) della cocciniglia asiatica Chionaspis wistariae Cooley, finora mai segnalata in Europa. La specie è stata raccolta su una vecchia pianta di glicine (Wisteria sp.) vegetante all'aperto ed è stata probabilmente introdotta accidentalmente insieme alla sua pianta ospite.
\end{abstract}

Key words: Wisteria sp., armoured scale insects, Encarsia citrina (Craw), Romania

\section{INTRODUCTION}

The botanical gardens are often a reservoir of alien pests due to the presence of exotic plants introduced from different areas of the world. The introduction of living plants can lead to the incidental introduction of their insect pests which, in some cases, may persist on their host plant in the new environment. If they are small, concealed and at low population levels, their presence can be undetected for years (Pellizzari \& Danzig, 2007; Pellizzari et al., 2010).

A visit to the University Botanical Garden of Cluj Napoca (Romania) led to the discovery of Chionaspis wistariae Cooley, an Asiatic diaspidid associated with Wisteria plants, not yet recorded outdoors in Europe. Wisterias are popular ornamentals, largely cultivated in Europe since XIX century when W. floribunda and W. sinensis were imported from Japan and China. 
Chionaspis wistariae Cooley, 1897

Syn: Phenacaspis fujicola Kuwana, 1931

On August 21, 2010 several white covers were observed on the leaves and petioles of an old Wisteria sp. tree (Fabaceae) growing outdoors, near the entrance to the greenhouses of the University Botanical Garden of Cluj Napoca (fig.1). Once mounted on slides the specimens were identified as Chionaspis wistariae, an Asiatic species so far not recorded outdoors in Europe.

At the collection date the following stages were present on the leaves: egg-laying females, eggs and crawlers. Several scales were holed by a parasitoids. Empty male puparia, white and tricarinate, were also observed. The scales were settled along the main or the secondary veins of the leaflets, both on the upper and lower surface; their number per leaflet did not exceed 25-30, apparently without any damage for the plant. The scales were almost evenly distributed on the leaves of the old Wisteria tree. This fact, the host specificity of this species and the presence of holed covers indicate that its incidental introduction probably occurred several years ago, together with its host plant.

\section{Host plants and distribution}

C. wistariae develops on Wisteria species (Wisteria brachybotrys, W. floribunda, W. multijuga, W. nankinensis, W. sinensis) (Liu et al., 1989; Malumphy, 2010, personal

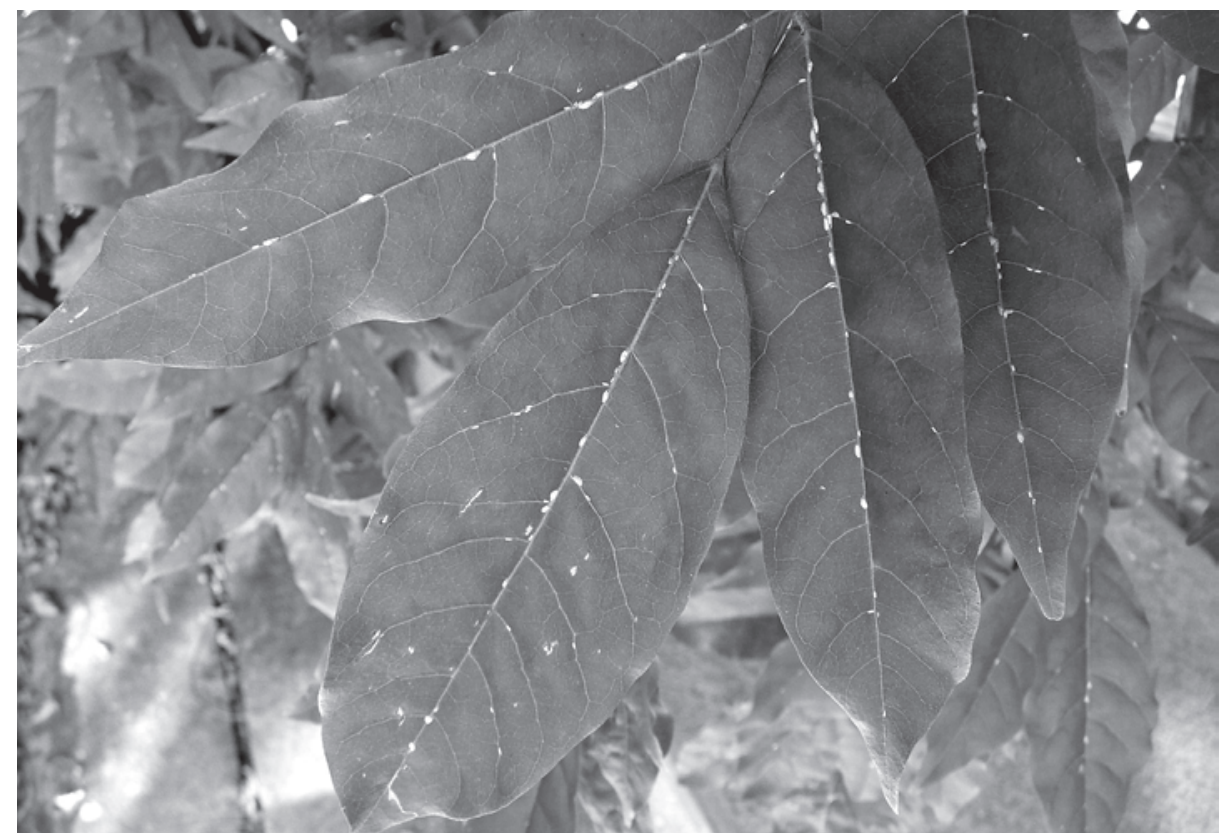

Fig. 1 - leaf of Wisteria sp infested by Chionaspis wistariae Cooley. 
communication). It was described on specimens first collected in California off Wisteria plants imported from Japan (Cooley, 1897). It is a supposed native of Japan and is present also in China. It has been intercepted several times in the U.S.A. on Wisterias imported from Japan, and has become established in California and Pennsylvania (Liu et al., 1989; Ben-Dov et al., 2010). According to Miller et al. (2005), it is not considered a pest over there.

With regard to Europe, between 1981 and 1990,C. wistariae was officially detected on six occasions at commercial plant nurseries in the UK (in the counties East Sussex, Norfolk and Surrey) on bonsai Wisteria brachybotrys and Wisteria floribunda imported from Japan (Naka-ku, Nagoya, Aichi prefecture and Yokohama, Kanagawa prefecture). In all cases, action was taken to eradicate the scale insects under the guidance of the U.K. Plant Health and Seeds Inspectorate authorities and all infested plants were destroyed (Malumphy, 2010, personal communication). Probably C. wistariae has been incidentally introduced with its host plant several times from Japan to European countries, even if we are aware only of the above reported cases.

\section{Notes on biology}

As with other Chionaspis species, $C$. wistariae has a white, oystershell-shaped cover, 1.5-2.5mm long (fig.2); the specimens settled on the petioles are distinctly longer than specimens settled on the leaf. Its biology is not known in detail but, as with other

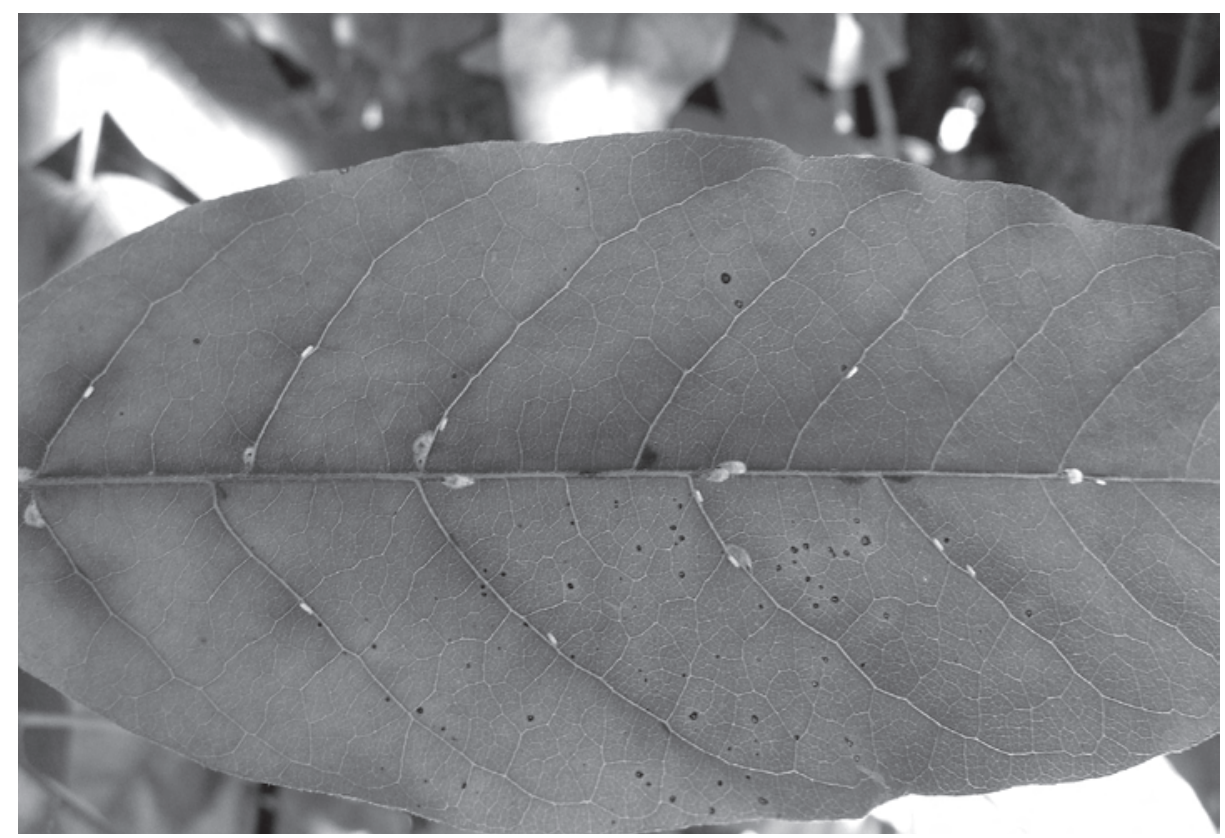

Fig. 2 - Wisteria leaflet with the white, oyster shaped covers of C. wistariae. 
Chionaspis species, it develops two generations/year: a summer generation that develops on the leaves and a second generation that settles on the bark and overwinters as adult female (Liu et al., 1989). The adult females of $C$. wistariae exhibit two morphological forms, linked to the feeding site, differing in the shape of pygidial lobes: the leaf-infesting form and the branch-infesting form. This host-site induced dimorphism is recorded also in other diaspidids: the two morphological forms of the same species are so dissimilar that, in the past, they were described and considered as separate species until the situation was clarified (Lupo, 1943; Takahashi, 1953; Takagi, 1961). A detailed account on this subject is reported by Liu et al. (1989) and by Takagi (1990).

A few parasitoids swarmed in laboratory from $C$. wistariae adult females when in Italy (August 28-30, 2010). They have been identified as Encarsia citrina (Craw) (Aphelinidae), a common solitary endoparasitoid of several armoured scale insects. $C$. wistariae is a new host of the above recorded Aphelinid.

\section{The scale insects of Wisteria sp.}

According to ScaleNet more than 20 different polyphagous scale insect species have been recorded on Wisteria trees, but none of these has proved to be a pest, with the exception of Eulecanium excrescens (Ferris) (Fam. Coccidae). This Asiatic soft scale, which has recorded also in the U.S.A., was first detected in Europe, London (UK), in 2001 and has since spread in south-east England, where outbreaks still occur (Malumphy, 2005; Salisbury et al., 2010). E. excrescens has also been recorded occasionally on other ornamental and fruit trees, but apparently Wisterias are the preferred host. According to Malumphy (2005), E. excrescens has one generation/year; the nymphs overwinter and reach maturity in April. The adult females lay eggs in May; crawlers emerge in May-June and settle on the leaves; in Autumn, before the leaves fall, they move from the leaves to the twigs to overwinter. Damage consists in sap sucking, excretion of honeydew and the development of black sooty mould which reduces the aesthetic value of the plant. With regard to $C$. wistariae, as reported above, no damage to the infested plant has been observed; this is in accordance with Miller et al. (2005), who consider that $C$. wistariae is not a pest of Wisterias in the U.S.A., where the scale was introduced more than one hundred years ago.

The University Botanical Garden of Cluj Napoca is, so far, the only European location where this species has been recorded outdoors; further investigations on old Wisterias trees growing outdoors will probably demonstrate a larger distribution of this species in Europe.

\section{AKNOWLEDGEMENTS}

Many thanks are due to Dr. C. Malumphy (Food and Environment Research Agency, Sand Hotton, York, UK) for his valuable and detailed information on Chionaspis wistariae interceptions, to Prof. Antonio Garonna (University of Naples, Italy) for the parasitoid identification and to C. Hodgson (The National Museum of Wales, Cardiff, UK) for kindly revising the manuscript. 


\section{REFERENCES}

Ben-Dov Y., Miller D. R., Gibson G. A. P., 2010 - ScaleNet: a database of the scale insects of the world. Available from: http://www.sel.barc.usda.gov/scalenet/scalenet.htm (accessed September 2010).

Cooley R.A., 1897 - New species of Chionaspis. - Canadian Entomologist 29: 278-282.

Kuwana S.I., 1931 -. The diaspine Coccidae of Japan. VI. Genus Phenacaspis. Scientific Bulletin (Ministry of Agriculure and Forestry, Japan) 2: 1-14.

Liu T., Kosztarab M., Rhoades M., 1989 - Biosystematics of the Adult Females of the Genus Chionaspis (Homoptera: Coccoidea: Diaspididae) of North America, with Emphasis on Polymorphism. - Virginia Polytech. Inst \& State University, Virginia Agricultural Experiment Station, Blacksburg, Bulletin 88-2:1-126

LuPo V., 1943 - Il Mytilococcus ficifoliae (Berlese) è una forma estiva del M. conchiformis (Gmelin) - Bollettino del R. Laboratorio di Entomologia Agraria. Portici 5: 196-205.

MALumPHY C.P., 2005 - Eulecanium excrescens (Ferris) (Hemiptera: Coccidae), an Asian pest of woody ornamentals and fruit trees, new to Britain.- British Journal of Entomology and Natural History 18(1): 45-49.

Miller D.R., Miller G.L., Hodges G.S., Davidson J.A., 2005 - Introduced scale insects (Hemiptera: Coccoidea) of the United States and their impact on U.S.- Agriculture. Proceedings of the Entomological Society of Washington 107 (1): 123-158.

PellizZARi G., DanZIG E., 2007 - The bamboo mealybugs Balanococcus kwoni n.sp. and Palmicultor lumpurensis (Takahashi) (Hemiptera, Pseudococcidae).- Zootaxa 1583: 65-68.

Pellizzari G., Cassina G., Cappelletti E.M., Frigimelica G., 2010 - The botanical Garden of Padua (Italy): a reservoir of alien insects and mites.- Book of Abstracts, $4^{\text {th }}$ Global Botanic Gardens Congress, $13^{\text {th }}-18^{\text {th }}$ June 2010, Dublin, Ireland: 132 (poster abstract ).

Salisbury A., Halstead A.J., Malumphy C., 2010 - Wisteria scale, Eulecanium excrescens (Hemiptera: Coccidae), spreading in South East England.- British Journal of Entomology and Natural History, 23: 4.

TAKAGI S., 1961 - A contribution to the knowledge of the Diaspididini of Japan (Homoptera: Coccoidea) Pt. II.- Insecta Matsumurana 24: 4-42.

TAKAGI, S. 1990 - Polymorphism. 59-64 In: Rosen, D. (Editor), Armored Scale Insects, Their Biology, Natural Enemies and Control. World Crop Pests, Vol. 4A, Elsevier, Amsterdam, The Netherlands: 384 pp.

TAKAHASHI R., 1953. Dimorphism in some species of Chionaspis or Phenacaspis. (Diaspididae, Coccoidea, Homoptera).- Bollettino del Laboratorio di Zoologia Generale e Agraria "Filippo Silvestri” 33: 48-56.

GiusePpina PellizZARI - Università di Padova, Dipartimento di Agronomia Ambientale e Produzioni Vegetali - Viale dell’Università 16,35020 Legnaro, Italy. E-mail: giuseppina.pellizzari@ unipd.it

Accepted 30 November 2010 